\title{
Halbyggeri mellem fag, politik og økonomi
}

Af Kim Furdal

\section{Indledning}

En gang i midten af 1970'erne var jeg sammen med andre konkurrencesvømmere på vej i en bus til et større svømmestævne i en sjællandsk provinsby. Da vi kom til byen, var buschaufføren lidt i vildrede med, hvor svømmehallen lå, hvilket fik træneren til at udbryde: »Kør efter et nybygget palads, så er det enten et rådhus eller en svømmehal «. Den lidt fordomsfulde bemærkning fra en 16-17-årig træner dækker imidlertid over en interessant iagttagelse. Kommunalreformen i 1970 havde sat gang i byggeriet af nye rådhuse, og fritidsloven fra 1968 parret med den generelle velstandsstigning havde sat gang i halbyggeriet. Det gjaldt ikke mindst byggeriet af de driftsøkonomisk meget dyre svømmehaller, der i disse år skød op som idrætslivets monumenter over velfærdsstaten.

Store offentlige midler, som reelt er indirekte tilskud til idrætslivet, er i landets kommuner bundet $\mathrm{i}$ idrætsanlæg lige fra atletik- og fodboldbaner og skolernes gymnastiksale til store samlede og multifunktionelle idrætshaller. På den baggrund er det bemærkelsesværdigt, hvor lidt vi egentlig ved om disse anlæg. Vi har end ikke et samlet overblik over omkostningerne ved driften af de mange anlæg. Anlæg drevet af selvejende institutioner lader sig ellers let gennemlyse, men spørger man om prisen for driften af en kommunal idrætshal evt. tilknyttet en skole, er omkostningerne fordelt på en lang række kommunale konti. Men også andre spørgsmål trænger sig på. Hvem var initiativtagerne til opførelsen af disse anlæg? Hvordan var forholdet mellem idrættens frivillige, de kommunale embedsmænd og lokalpolitikerne i forbindelse med etableringen? Hvilken betydning har de skiftende lovgivninger haft på byggerierne og driften af idrætsanlæggene? Og hvilken betydning har drifts- og finansieringsformen haft på idrætslivet? Disse og mange andre spørgsmål blæser i vinden.

I det følgende skal vi se nærmere på de processer i Aabenraa kommune, der førte til opførelsen af Aabenraa Svømme- og Idrætshal i perioden 1971-1973. Afsættet for at bygge en svømmehal i Aabenraa begyndte allerede i slutningen af 1940'erne, og det lange sagsforløb blotlægger de mange overvejelser og konflikter gennem mere end to årtier, som førte til et mål, der langt fra var givet på forhånd, og i dette perspektiv er sagen interessant. ${ }^{1}$

\section{Søbadeanstalten i Aabenraa}

I slutningen af 1940'erne havde Aabenraa en søbadeanstalt på spidsen af Gammelhavns sydlige mole. Her havde byens borgere badet gennem årtier, og her blev byens skoleelever undervist i svømning. Aabenraa Andels-Svineslagteri, der blev anlagt $\mathrm{i}$ 1922 kun få hundrede meter fra søbadean- 
stalten, udledte i kølvandet på slagteriets stigende produktion i mellemkrigsårene mere og mere spildevand. At det ikke altid var lige rare sager, der blev sluppet ud i fjorden, kan ældre borgere endnu fortælle: blod og »rester « fra slagteriet flød i vandet ved søbadeanstalten. Men også byens borgere bidrog til den store offentlige kloak i de åbne vandløb og vandet omkring havnebassinet, ligesom eksportstaldene i nærheden, hvor kreaturerne under »transporten til og fra staldene bidrog til forureningen. Bodil Vinding Bjarnt har i sine erindringer meget malende beskrevet situationen: »I 1950'erne eksporteredes levende kvæg over Aabenraa havn. Når køerne skulle ind- skibes, foregik det med el-stave i rumpen på dem. De arme dyr blev så bange, at de sprang op på hinanden og sked. Dette affald blev nu fejet ned i havnen. Tit og mange gange har vi en sommermorgen, når vi skulle ned og bade før eksamenslæsning, set på dette uhyggelige skuespil. Bagefter cyklede vi lidt længere ud til søbadeanstalten, hvor vi stod og så diverse »ting « flyde forbi. Når vandet så rimeligt klart ud, sprang vi på hovedet $\mathrm{i} \ll$. Søbadeanstalten bidrog imidlertid også selv til forureningen. Når badeanstaltens latrin var fyldt, tog bademesteren spanden og tømte den på spidsen af molen. De badende svømmede i bogstaveligste forstand i det affald, som andels-
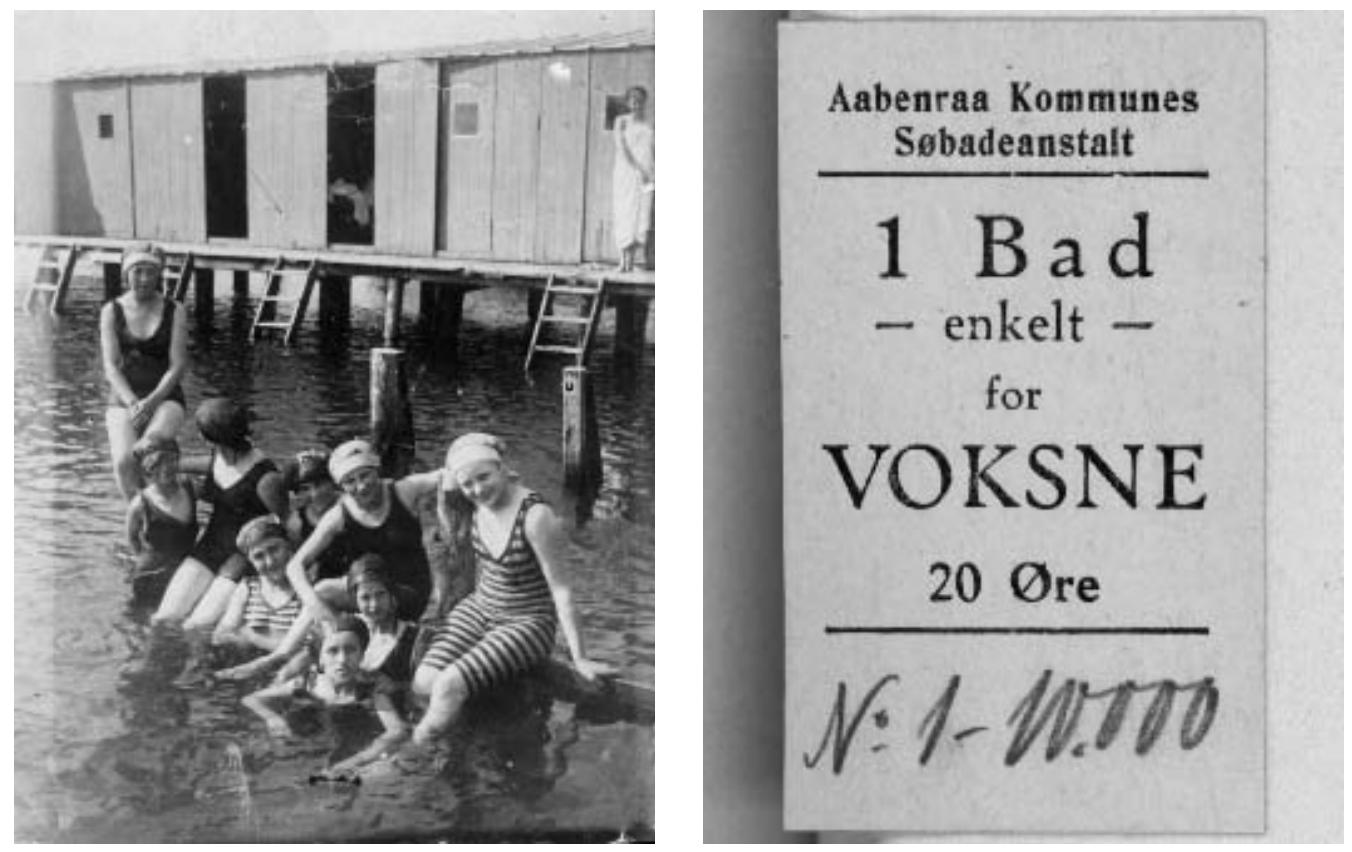

Aabenraa Søbadeanstalt har en historie, der rakker tilbage til begyndelsen af 1800-tallet, da en entreprenant lage August Wilhelm Neuber i 1820 fik etableret en international søbadeanstalt på nordsiden af Aabenraa fjord. Badeanstalten fik dog en kort levetid, og $i$

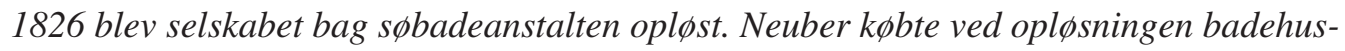
ene og badevognene og drev frem til sin d $\phi d i 1841$ en sфbadeanstalt, som formentlig er forlфberen for søbadeanstalten på spidsen af molen ved Gammelhavn. Her poserer en gruppe unge piger foran fotografen. Til højre ses en entrebillet til søbadeanstalten fra begyndelsen af 1920'erne. Foto: Institut for Sønderjysk Lokalhistorie. 
slagteriet, eksportstaldene, byens kloakker og de badende selv lukkede ud i havnen.

Dette var sundhedsmyndighederne allerede klar over i slutningen af 1938, uden at kommunen dog gjorde noget ved problemet, og først i 1948 nedlagde Sundhedskommissionen et forbud mod tvungen skolebadning. Forbuddet var ikke blot et problem for eleverne, der ikke kunne modtage svømmeundervisning, men også for Aabenraa kommune. Allerede i folkeskoleloven fra 1937 blev det påbudt kommunerne at tilbyde svømmeundervisning, hvor det var muligt, forstået som kommuner med mindre end en $\mathrm{km}$ til badestrand eller egnede søer. Loven gjaldt ikke de sønderjyske landsdele. ${ }^{2}$ Formelt juridisk gjaldt loven altså ikke skolevæsenet i Aabenraa, men politisk var det et problem at overhøre loven og cirkulærets generelle budskab, når byen lå lige ved vandet og havde gode badestrande. Samtidig var det vanskeligt at præsentere de nye svømmeprøver for eleverne, når man ikke kunne tilbyde den undervisning, som var forudsætningen for, at eleverne kunne aflægge prøverne. Sagen var altså politisk prekær for byrådet, ikke mindst når løsningen på problemet rent teknisk var relativt enkel, hvis man var villig til at investere de nødvendige midler.

Sundhedskommissionens forbud satte derfor en politisk proces $i$ gang for at finde en løsning og fra politisk hold helst en billig løsning. Fra svømmeklubbens side blev der fra starten meldt klart ud, at den bedste løsning var et friluftsbad indrettet således, at den kunne få en overbygning, når det blev $\varnothing$ konomisk muligt, men den løsning var ikke spiselig for byens politikere, der i stedet satsede på at bygge en ny badeanstalt på Sønderstrand. Og det lykkedes faktisk efter betydelig politisk diskussion at få opført en ny søbadeanstalt i 1963 efter en finansieringsmodel, der i sig selv er et studium værd. ${ }^{3}$

Dermed havde Aabenraa fået en ny søbadeanstalt, der kunne anvendes til skolernes svømmeundervisning. Men det skete på et tidspunkt, hvor søbadeanstalternes epoke var på vej over i historien. ${ }^{4}$

På grund af forureningen havde Aabenraa Svømmeklub allerede i 1954 opgivet svømmeundervisningen uden udsigt til at kunne genoptage den. Op gennem 1950'erne rykkede svømmeklubben sammen med Samvirkende Idrætsforeninger i Aabenraa (S.I. K.A.) jævnligt for en løsning, der helst skulle være et friluftsbad, som den eneste $»$ rationelle løsning $\ll .5$

For at understrege kravet iværksatte Aabenraa Svømmeklub og S.I.K.A. i 1957 en større indsamling blandt byens idrætsforeninger, som imidlertid $l ø b$ ud i sandet. Indsamlingen til en svømmehal var vanskelig at sælge til medlemmerne af f.eks. Aabenraa Boldklub, som ikke direkte havde gavn af hallen. Formanden for S.I.K.A., Hans Johansen, gjorde derfor ved generalforsamlingen i 1958 meget ud af at forklare, hvorfor alle klubber skulle bakke op omkring indsamlingen.

Det sympatiske og idealistiske ønske om genindførelse af svømmeundervisning i Aabenraa var der næppe mange, der kunne være uenige i. Men ved netop at understrege den elementære svømmeundervisning for børn, »skoleundervisning «, og nedtoningen af Aabenraa Svømmeklub, nedtonede han også de krav, som svømmeklubben stillede til aktiviteter som svømmemotion, konkurrencesvømning, udspring og vandpolo. Dermed spillede erklæringen også på et underliggende skisma mellem svømmeundervisning af børn (skoleundervisning) og svømning som familiens »totalidræt « for at anvende et udtryk, som Dansk Svømme- og Livredningsforbund 
karakteriserede svømmeidrætten med i slutningen af 1970'erne. Netop dette skisma kom til at spille en afgørende rolle for den politiske debat om et svømmebassin i Aabenraa, selv om aktørerne næppe selv var klar over det.

\section{Store visioner og et svømmebadsmarked}

Målet med indsamlingen blev ikke nået, og Aabenraa stod stadig uden mulighed for at tilbyde svømmeundervisning. Ved udgangen af 1950'erne kunne S.I.K.A. stadig pege på forureningen af fjorden og de manglende muligheder for at tilbyde elementær svømmeundervisning til børn og unge. Selv om det ikke indgik i debatten, så havde skoleeleverne i Aabenraa Kommune på dette tidspunkt også fået et retskrav på svømmeundervisning i skolerne. ${ }^{6}$ Dermed var ideen om et friluftsbassin for alvor kommet på banen hos byrådspolitikerne. Det var næppe heller tilfældigt, at magistraten den 8. december 1959 bad skole- og ungdomsudvalget om at tage stilling til spørgsmålet. Dermed blev svømmesagen flyttet fra stadionudvalget med fokus på sagens idrætsmæssige aspekt til skole- og ungdomsudvalget, der i sagens natur vægtede undervisningen i folkeskolen og skolernes interesser højere.

Afgørende blev det, da S.I.K.A. i sommeren 1960 bad om tilladelse til at starte en husstandsindsamling til fordel for et friluftsbad. Først lykkedes det byrådet ved en aktiv indsats at få indsamlingen standset gennem politimesteren, men i november 1960 indkaldte kommunen Aabenraa Svømmeklub og S.I.K.A. til et møde om en husstandsindsamling. Omsvinget $\mathrm{i}$ byrådets holdning til indsamlingen er lidt uklar, men der er næppe tvivl om, at man øjnede en chance for at få en svømmehal til skoleundervisning delvis finansieret ved en indsamling blandt byens borgere. I alt fald blev der i første omgang nedsat et udvalg bestående af repræsentanter fra kommunen og idrætslivet med formanden for Aabenraa Svømmeklub, Nis Jørgensen, som formand. Udvalget skulle fremkomme med forslag til indretning af et friluftsbassin til brug for i første række skolernes svømmeundervisning. Den 9. december 1960 havde udvalget sit første møde, hvor begejstringen må have fået frit $1 \varnothing b$. Mødet førte til en anmodning om, at stadsingeniøren udarbejdede et forslag til indretning af et friluftsbad på skolesportspladsen ved Callesensgade bestående af ikke mindre end to bassiner, et »undervisningsbassin « på $12,5 \times 12 \mathrm{~m}$ og et »træningsbassin « på $12,5 \times 25 \mathrm{~m}$. I tilknytning til de to bassiner skulle der opføres en omklædningsbygning beregnet til omklædning for tre klasser ad gangen. Det var et meget ambitiøst projekt, der tilgodeså såvel svømmeklubbens som skolernes behov. ${ }^{7}$ Projektet tilfredsstillede dermed alle parter.

Det stort anlagte svømmebadsmarked den 27. og 28. maj 1961 blev en bragende succes, men da man nåede op på $62.000 \mathrm{kr}$. løb man ind i et byggestop, som stoppede indsamlingen.

\section{Begyndende politisk splittelse}

Da byggestoppet blev ophævet, kunne man tage fat på svømmebadssagen igen, men nu var der kommet helt nye aspekter ind i sagen. Skolevæsenet i Aabenraa havde været inde $\mathrm{i}$ en rivende udvikling, efterhånden som efterkrigstidens store fødselsårgange nåede skolealderen $\mathrm{i}$ begyndelsen af 1950'erne. I efteråret 1962 satte byrådet derfor gang i projektering af en ny og større skole. 
Den ny skole blev den konkrete anledning til, at formanden for skole- og ungdomsudvalget i december 1962 indkaldte formanden for svømmehalsudvalget, Nis Jørgensen, til et møde om sagen. Nis Jørgensen kunne fortælle, at man stadig arbejdede med planerne for et friluftsbad, men at der endnu ikke var fastlagt nogen placering af badet. Først den 31. januar 1964 nedsatte byrådet et udvalg, der skulle undersøge, hvorledes svømmeundervisningen i kommunen fremover skulle løses. Nedsættelsen af udvalget blev mere afgørende for svømmebadssagen end svømmeklubbens og S.I.K.A.'s nye formand, Nis Jørgensen, formentlig brød sig om. Ind til dette tidspunkt havde svømmeklubben og S.I.K.A. spillet en central rolle som motor og katalysator for opførelsen af et svømmebad. Gennem 1950'erne havde Aabenraa Svømmeklub og S.I.K.A. hele tiden forsøgt at holde politikerne fast på deres forpligtelse til at sikre svømmeundervisningen i Aabenraa. Det var således svømmeklubben og S.I.K.A., der omkring 1960 for alvor satte skub i sagen med deres indsamling blandt idrætsforeningernes medlemmer og ansøgning om en husstandsindsamling. Nu flyttede sagen over $\mathrm{i}$ et rent kommunalt udvalg og byrådet, hvilket betød en hidtil ukendt politisering af sagen, men ikke nødvendigvis en hurtigere sagsbehandling.

Politikerne i det nye udvalg fastholdt det oprindelige forslag med et friluftsbassin bestående af to bassiner, et stort med internationale mål og et lille bassin til undervisning af de mindste skoleelever. Selve løsningen med to bassiner tog rigelig hensyn til såvel skolernes som svømmeklubbens behov og gav ikke anledning til diskussion. Anderledes forholdt det sig med placeringen i tilknytning til en af skolerne, der angav vægtningen mellem skolesvøm- ning og svømning som idræt med et bredere behov. Formanden for skole- og ungdomsudvalget og tidligere borgmester, Georg Buchreitz (S), ønskede en placering ved en af skolerne, men den blev afvist af borgmesteren, Erik Jessen (Borgerlig Fællesliste), som ønskede svømmebadet placeret $\mathrm{i}$ tilknytning til stadion. Da det rådgivende ingeniørfirma Ostenfeld \& W. Jønson i november fremsendte et anlægs- og driftsoverslag, indeholdt det ikke blot et forslag for et friluftsbad som ønsket af byrådet, men også for en svømmehal. Det kan ikke afvises, at firmaet på eget initiativ sendte overslaget på en svømmehal vel vidende, at man spillede med på de lokalpolitiske tangenter og, som det senere vil fremgå, ikke uden held. Politikerne måtte dog også konstatere, at den generelle prisudvikling havde sat sine mærkbare spor på anlægs- og driftsomkostningerne. En svømmehal med internationale mål kunne Ostenfeld \& W. Jønson realisere for ca. 2.300.000 kr., som bandt kommunen for 500.000 kr. i årlige driftsomkostninger. ${ }^{8}$

Det må formentlig have fået det til at gibbe i nogle af byrådspolitikerne, da de gennemgik materialet. I første omgang arbejdede borgmester Erik Jessen dog videre på en placering af svømmebassinet. Samtidig med Erik Jessens overvejelser omkring placeringen var flere medlemmer af det kommunale svømmebadsudvalg i foråret 1965 ved at opgive projektet vedrørende et friluftsbad til fordel for en svømmehal. Dette stemningsskifte blev støttet af Ostenfeld \& W. Jønson, der havde tilsendt kommunen en oversigt over besøgstal for svømmehaller i Roskilde, Sønderborg, Svendborg og Odense, som viste, at en svømmehal var den bedste investering. Og i juni 1965 var »stemningsskiftet « en realitet. Den 10. juni indstillede to af udvalgets medlemmer, Erik Jessen og Nic. Jespersen (Borgerlig 
Fællesliste), at der blev udarbejdet et skitseprojekt til et friluftsbad, mens Dycke Hoff (S) og Marguerite Hahnemann (C) anbefalede, at man i stedet fik udarbejdet et skitseprojekt til en svømmehal. Hans Callesen (S) forbeholdt sig sin stilling mens de $\emptyset$ vrige to medlemmer var fraværende. Selv om udvalget var delt i spørgsmålet mellem den borgerlige fløj med Erik Jessen i spidsen og Socialdemokratiet ledet af Georg Buchreitz (S), så markerede mødet et brud med den hidtidige, enstemmige opbakning omkring et friluftsbad.

For at inddæmme denne splittelse bad magistraten ( $\varnothing$ konomiudvalget) i efteråret 1965 Ostenfeld \& W. Jønson om at se på muligheden for at opføre et friluftsbassin med en senere luftbåret plastikoverbygning i lighed med Tåstrup friluftsbassin. Til trods for rapporten fra firmaet, der omtalte betydelige kondensproblemer og et uinspirerende svømmehalsmiljø, valgte skole- og ungdomsudvalget denne væsentligt billigere løsning. Samtidig valgte skole- og ungdomsudvalget en placering lige syd for den nye Brundlund skole, men uafhaengig af skolen. Ved at bringe plastikoverdækningen ind i debatten var det lykkedes Erik Jessen på ny at opnå enighed i udvalget, så man i begyndelsen af 1966 kunne indhente et skitseprojekt og et overslag hos det rådgivende ingeniørfirma over anlægsomkostningerne for et friluftsbassin med mulighed for en luftbåret plastikoverdækning. Erik Jessen skubbede dermed friluftsbadet ud af skolernes regi, men placerede badet meget tæt på byens to skoler, således at løsningen også tilgodeså skolernes behov.

Det skulle imidlertid vise sig, at vejen til indvielsen af svømmehallen ikke var så ligetil endda. I marts 1967 var der møde i skole- og ungdomsudvalget, hvor formanden, Georg Buchreitz (S), fremsatte et for- slag om at etablere en svømmehal mellem de to gymnastiksale ved Rugkobbelskolen med adgangsvej fra Tøndervej og Stadion. Dermed var hele diskussionen omkring svømmesal/svømmehal/svømmebad på ny kastet ind i debatten, hvilket udskød en igangsætning af projektet. Reaktionen udeblev ikke i pressen, hvor avisspalterne i foråret 1967 flød over af en heftig diskussion omkring svømmebadet. Under overskriften »Kombineret svømme- og idrætshal « rykkede Elna Rasmussen i Hejmdal for handling i sagen og spurgte retorisk »alle taler om, hvad der burde gøres, men hvem gør noget ved det? « Selv borgmester Erik Jessen gik ud i pressen med et indlæg, hvor han argumenterede for en løsning, der tilgodeså såvel svømmeundervisningen som kravet om internationale mål til svømmestævner. Han ønskede et friluftsbassin, der var godt $270.000 \mathrm{kr}$. billigere i drift om året end en svømmehal. Selve kombinationen af en svømmehal og en idrætshal blev meget bastant afvist af Erik Jessen, da løsningen efter hans opfattelse var for dyr både i udførelse og adm. Dermed trak diskussionen linierne op mellem på den ene side primært »Borgerlig Fællesliste« med borgmester Erik Jessen i spidsen, der ønskede et friluftsbassin, som var billigere end en svømmehal, men som også tilgodeså idrætslivet, og på den anden side Socialdemokratiet, der foretrak den dyrere svømmehal, som først og fremmest skulle dække skolernes behov for en hal til undervisning af eleverne.

På baggrund af avisdebatten fandt Ostenfeld \& W. Jønson den 1. juni 1967 det nødvendigt at gøre rede for deres synspunkter i sagen. I to breve til Erik Jessen anførte W. Jønson bl.a., at en svømmesal ikke tilfredsstillede de $\emptyset$ nsker, som skolerne, svømmesporten og det almindelige publikum »med rette må fremsætte«, idet 
han henviste til læseplanudvalgets betænkning fra 1960/61. Den meget ligefremme anbefaling af et projekt, som gik lodret imod borgmester Erik Jessens synspunkter i sagen, var formentlig en væsentlig del af forklaringen på, at firmaet senere gled ud af arbejdet med projekteringen af svømmebassinet.

\section{En svømme- og idratshal}

På dette tidspunkt var der imidlertid ved at komme andre aspekter ind i spørgsmålet. I S.I.K.A.'s årsberetninger for 1962 og 1963 udtalte formanden Nis Jørgensen, at der hurtigst muligt burde arbejdes for opførelsen af en idrætshal i Aabenraa. Man havde siden 1956 haft Sønderjyllandshallen, men den var ikke en idrætshal, men en hal, som skulle varetage mange opgaver fra badmintonstævner til skuespil, udstillinger og koncerter. Tonen blev strammet de følgende år, hvor Nis Jørgensen pegede på to faktorer, som pressede sig på, fuldførelsen af svømmebadsprojektet og bygningen af en idrætshal. Sønderjyllandshallen var ganske enkelt ikke længere i stand til at imødekomme klubbernes behov for halkapacitet.

På denne baggrund indledte S.I.K.A. og Aabenraa Amts Firmasport i slutningen af 1967 et samarbejde for at bygge og drive en idrætshal, formaliseret $i$ et haludvalg »Aabenraa-Hallen «. I december 1967 henvendte udvalget sig til Aabenraa Kommune og fik ikke mindre end to møder i stand den 12. december, begge i en positiv atmosfære. Her foreslog haludvalget en løsning, hvor opførelsen af idrætshallen blev finansieret ved gratis arbejde, indsamlinger og kommunale midler, hvorefter idrætshallen blev drevet som en selvejende institution. ${ }^{9}$ Tilsyneladende har man også på dette møde drøftet at bygge idrætshallen i tilknytning til svømmehallen som et idrætskom- pleks ved Hjelmallé, så man kunne udnytte svømmehallens omklædningsrum. Dermed var der kastet helt nye bolde ind i diskussionen om den fremtidige svømmehal, som skulle komme til at spille en afgørende rolle for svømmehallens fremtid. At velviljen også havde sine grænser, fik haludvalget allerede at mærke på det andet møde samme dag, hvor haludvalget havde et teknikermøde med stadsarkitekt Robert Flade og ingeniør Günther Oesten fra det rådgivende ingeniørfirma af samme navn. Her redegjorde Robert Flade for kommunens skitserede planer og understregede i den forbindelse, at haludvalget ifølge aftalen blot skulle arbejde med den nøgne hal, mens kommunen skulle opføre omklædningsbygningen, kantinen m.m. Haludvalget forstod budskabet. Idrætslivets deltagelse i arbejdet med opførelsen, som den blev opfattet i Aabenraa Kommune, havde sine klare grænser, så ordet »blot « var understreget $i$ haludvalgets referat fra $m \varnothing$ det. ${ }^{10}$

Det lille ord »blot« har nok generet haludvalget, men ødelagde ikke på overfladen den gode stemning efter møderne. Allerede $i$ begyndelsen af 1968 tog idrætsforeningerne fat på arbejdet med at finansiere idrætslivets andel af omkostningerne. Den 22. april kunne borgmester Erik Jessen byde velkommen til et orienterende møde med de fremtidige brugere af Aabenraa-Hallen, idet han understregede, at forhandlingerne mere måtte betragtes som orienterende. Herefter kunne Nis Jørgensen oplyse forsamlingen om, at S.I.K.A. og Aabenraa Amts Firmaidræt i fællesskab havde dannet en selvejende institution »Aabenraa-Hallen, der skulle opføre og drive en fremtidig idrætshal i Aabenraa«. Hallen ville skønsmæssigt koste ca. 1.2 mill. kr., hvoraf de $300.000 \mathrm{kr}$. skulle skaffes ved frivilligt arbejde. Men udgifterne kunne også nedbringes på anden vis. Nis 
Jørgensen foreslog derfor, at hallen og svømmehallen kunne opføres, så de kunne benytte et fælles omklædningsrum.

Hele etableringen af den selvejende institution »Aabenraa-Hallen « og involveringen af borgmester Erik Jessen var lidt af en genistreg af S.I.K.A. og Aabenraa Amts Firmaidræt. Idrættens organisationer i Aabenraa havde dermed sat sig selv solidt med foden på speederen, så de to foreninger selv kunne sætte tempoet på projektet, måske belært af tempoet for etableringen af svømmehallen. I princippet kunne idrætsforeningerne med de to organisationer i spidsen nu selv gå i gang med byggeriet, men da projektet realistisk krævede kommunal opbakning og økonomisk støtte, havde man i Erik Jessen fået den helt centrale politiske nøgleperson ind i bestyrelsen. Samtidig var det blevet betydeligt vanskeligere for byrådet at stoppe eller forsinke processen, da ingen politikere normalt vil stille sig i en position, hvor de står som stopklods for et projekt, der nyder bred opbakning i kommunen. Endelig havde Aabenraa Kommune mistet sin afgørende indflydelse på projektets udformning, omfang og pris. Det skal dog understreges, at konstruktionen på ingen måde var et særsyn for Aabenraa Kommune. Den dukkede op i mange kommuner i disse år, hvor man ønskede idrætshaller, hvilket bl.a. var tilfældet i Agerskov i første halvdel af 1970'erne. ${ }^{11}$

Det vidste Erik Jessen udmærket ligesom byrådets $\varnothing$ vrige medlemmer. For byrådet gjaldt det om at manøvrere sig ind $\mathrm{i}$ en central position, hvor man kunne vinde indflydelse på hallens udformning og dermed på kommunens fremtidige $\varnothing$ konomiske forpligtigelser. Og Erik Jessen var ikke sen til at handle. På et møde med skole- og ungdomsudvalget i maj 1968 fik Erik Jessen udvalgets opbakning til, at Aabenraa
Kommune overtog ansvaret for opførelsen af »Aabenraa-Hallen «. Det tilbud ville bestyrelsen for den selvejende institution kun meget vanskeligt kunne sige nej til. Opførelsen af en hal med dimensioner, så man kunne afholde internationale kampe krævede en betydelig viden og arbejdsindsats, som bestyrelsen kun vanskeligt kunne honorere. Ved at sige ja til kommunens tilbud fik man kommunens arkitekter og ingeniører til at stå for det store arbejde og ansvar for opførelsen af hallen, hvorefter bestyrelsen for den selvejende institution kunne overtage hallen. Til gengæld måtte bestyrelsen også acceptere, at Aabenraa Kommune fik en betydelig indflydelse på udformningen og dermed udgifterne til såvel opførelsen af hallen som de fremtidige driftsomkostninger.

Herefter gik det stærkt. Den 10. juni 1968 havde skole- og ungdomsudvalget med Erik Jessen i spidsen en drøftelse med bestyrelsen for Aabenraa-Hallen om finansieringen. Han fremførte, at Aabenraa Kommune som største bidragyder skulle stå for opførelsen og driften af hallen. Det var strengt taget en »forhandlingstaktisk « stramning i forhold til skole- og ungdomsudvalgets beslutning, men den gav mulighed for at give halbestyrelsen indrømmelser. Det blev der også brug for. De frivillige i haludvalget var langt fra begejstret for at overlade opførelsen og driften til Aabenraa Kommune. Her var det en klar forudsætning for S.I.K.A. og Aabenraa Amts Firmaidræt, at idrætten blev medbestemmende med hensyn til driften. »Efter nærmere eftertanke « mente Erik Jessen dog, at hallen kunne stilles til rådighed for S.I.K.A. og Aabenraa Amts Firmaidræt gennem et særligt haludvalg i kommunalt regi uden dermed at opgive det kommunale ejerskab. Denne løsning blev accepteret af S.I.K.A og Aabenraa Amts Firmaidræt. 
Det skulle være Aabenraa Kommune, der ejede og administrerede hallen, men den tanke tiltalte tydeligvis ikke Svend E. Falkenberg fra Aabenraa Amts Firmaidræt, som fremførte, at det ville afholde mange fra at yde en frivillig arbejdsindsats, hvis hallen blev kommunal. Herefter var Erik Jessen klar over budskabet og spurgte, hvorvidt vedtægterne kunne ændres, så den selvejende institution »Aabenraa-Hallen« alene fik til formål at opføre hallen i samarbejde med kommunen. Med dette juridiske raffinement kunne kommunen snog sig uden om problemet med den frivillige arbejdskraft. Det lige så raffinerede forhandlingstaktiske svar kom fra Elna Rasmussen fra halbestyrelsen, der oplyste, at indsamlingen af arbejdstimer foreløbig var standset, indtil der var skabt nærmere klarhed over byggeriet. Underforstået, at den ikke ville blive genoptaget, hvis der ikke kom en tilfredsstillende løsning for de frivillige. Dermed var spørgsmålet om ejerskabet fastlåst. Bestyrelsen for AabenraaHallen sad med nøglen til godt $25 \%$ af finansieringen, som de frivilliges arbejdskraft udgjorde. Det gav S.I.K.A. og Aabenraa Amts Firmaidræt en stærk forhandlingsposition i forhold til Aabenraa Kommune.

Mødet den 10. juni 1968 blev afgørende for etableringen af Aabenraa Svømme- og Idrætscentre. Ganske vist var der ikke opnået enighed om, hvem der skulle drive hallen, men da det afgørende for borgmester Erik Jessen var, at kommunen ikke fik en sekundær placering i hallens ledelse, og da udvalget ikke havde taget stilling til det fremtidige ejerforhold, var der rigeligt med forhandlingsrum til at tilfredsstille begge parter. Reelt havde Erik Jessen med sin drevne forhandlingstaktik fået sin vilje på mødet. Fire dage senere besluttede skoleog ungdomsudvalget at anbefale magistra- ten, at der blev udarbejdet et skitseprojekt til en hal med en håndboldbane og plads til 1.000-1.500 tilskuere under forudsætning af, at idrætten selv stillede med mindst $200.000 \mathrm{kr}$. eller arbejdskraft for dette beløb, og hallen i $\varnothing v$ rigt blev stillet til rådighed for idrætten i vinterhalvåret efter samme retningslinier som for stadionet. Samlet set var forslaget en indrømmelse til idrætten og et tegn på velvilje, uden at »skitseforslaget « gav nogen form for mur og nagelfaste løfter. Det kunne barberes ned mange gange, indtil projektet nåede det beløb, som Aabenraa Kommune var villig til at kaste ind i byggeriet og driften.

\section{Svømmeundervisning og breddeidroet}

Da formanden for S.I.K.A., Nis Jørgensen, i april 1968 fremførte sit ønske om, at idrætshallen og svømmehallen blev opført på en sådan måde, at man kunne bruge fælles omklædningsrum, blev det meget kategorisk afvist af Erik Jessen, der ikke ønskede spørgsmålet om svømmehallen inddraget i diskussionen. Det gjorde han klogt i. Aabenraa svømmebad var på dette tidspunkt ved at udvikle sig til et højprofileret lokalpolitisk emne, der ikke fremmede en afgørelse i sagen. I juni 1968 lå »aben« atter på skole- og ungdomsudvalgets bord, og nu var den tidligere politiske samdrægtighed forvandlet til en åbenlys splittelse. En gruppe indstillede, at der blev udarbejdet et detailprojekt til et friluftsbad med en omklædningsbygning, der også kunne anvendes af en kommende idrætshal. Over for dette forslag stod en indstilling om, at man skulle opgive friluftsbadet og i stede opføre henholdsvis en svømmesal og en svømmehal med internationale mål $(25$ x $12,5 \mathrm{~m})$ ved Rugkobbelskolen. I første omgang fast- 
holdt magistraten beslutningen om at få udarbejdet et detailprojekt for et friluftsbad lidt syd for den nye Brundlund skole i overensstemmelse med Erik Jessens $\emptyset$ nske, men med den vigtige tilføjelse, at sagen skulle sendes tilbage til skole- og ungdomsudvalget, der skulle indhente overslag over anlægsomkostningerne for såvel en svømmehal som en svømmesal ved Rugkobbelskolen. Et sandt politisk kompromis, som byrådet med Erik Jessen mestrede, men som ikke fremmede tempoet i beslutningsprocessen. Tilhængerne af en svømmehal ved Rugkobbelskole fik en imødekommelse i sagen samtidig med, at der blev arbejdet videre med detailprojektering af et friluftsbad. I bedste fald kunne Erik Jessen håbe på, at projekteringen af friluftsbadet var så langt fremme, når udtalelserne og overslagene forelå, at tilhængerne af en løsning ved Rugkobbelskolen - dvs. overvejende socialdemokraterne - stod med en dyrere løsning, mens modstanderne af denne løsning kunne præsentere et detailprojekteret friluftsbad syd for Brundlundskolen.

I begyndelsen af august 1968 forelå så overslagene for en svømmesal og svømmehal ved Rugkobbelskolen samt ekstraudgifterne, hvis omklædningsbygningen til en idrætshal også skulle anvendes af et friluftsbad om sommeren.

Dermed havde byrådet fået de ønskede oplysninger. Efter 20 års diskussioner om svømmeundervisning og svømmefaciliteter for byens unge var afgørelsens time kommet, hvilket skete på et byrådsmøde den 27. juni 1968. Og her blev der rig lejlighed for medlemmerne til at udfolde deres retoriske evner i en politisk marathondebat på over tre timer. Erik Jessen pointerede, at skole- og ungdomsudvalget var blevet enige om i fællesskab med idrættens organisationer at opføre en idrætshal, der skulle overdrages til kommunen, når den stod færdig. Byggeriet skulle sættes i gang, så snart idrætten havde skaffet $200.000 \mathrm{kr}$. eller frivillige og gratis arbejdstimer for et tilsvarende beløb, som det oprindelig var tilfældet med opførelsen af et friluftsbas$\sin$.

Men Erik Jessen fik ikke sin vilje! Efter den heftige og langvarige diskussion faldt afgørelsen ved håndsoprækning, og Erik Jessen måtte se, at det forslag om et friluftsbad, som han gennem alle årene havde forfægtet, faldt med et brag. I slutningen af 1950'erne var et friluftsbad endnu et flot og smukt alternativ til en søbadeanstalt ved stranden, men den stigende velfærd havde op gennem 1960'erne sat nye standarder for offentlige svømmefaciliter, der i befolkningens øjne gjorde løsningen »gammeldags «. Kravet var nu mulighed for svømning hele året i en svømmehal. Derfor $\varnothing$ nskede flertallet i byrådet nu en svømmehal i tilknytning til de eksisterende gymnastiksale på Rugkobbelskolen.

\section{»Die Badesaison nimmt kein Ende mehr«}

Med byrådets beslutning den 27 . august 1968 var der i alt fald på et område ryddet op i debatten, nemlig i spørgsmålet om hvilken type svømmebad, der skulle opføres. Tiden skulle dog snart vise, at afgørelsen om svømmehallens fysiske placering ikke var så endegyldig, som byrådsflertallets størrelse antydede. I slutningen af oktober 1968 var sagen på ny i byrådssalen, hvor forslaget efter nogle politiske og meget personlige trakasserier blev vedtaget med ni stemmer mod otte.

Den 9. december 1968 forelå en skitse fra ingeniør Günther Oesten til en svømmehal ved Hjelmallé, hvis placering var i overensstemmelse med det to år gamle for- 
slag fra Ostenfeld \& Jønson, og som svarede til løsningen ved Rugkobbelskolen.

Med ingeniør G. Oestens tal for omkostningerne ved de to løsninger frafaldt de medlemmer, der gik ind for en svømmehal ved Rugkobbelskolen, og de medlemmer, som gik ind for et friluftsbad ved Hjelmallé, deres ønsker til fordel for en svømmehal ved Hjelmallé. Formuleringen er interessant ved ikke at være noteret som en konstateret enighed, men som et forhandlingsresultat mellem to parter i en sag. Det siger nok noget om den heftighed, hvormed sagen blev diskuteret, at ingen ville opgive deres synspunkter i sagen og dermed tabe ansigt. I stedet måtte man formulere sig ud af problemet, så begge parter opgav deres standpunkter for at gå sammen om en ny løsning. Socialdemokraterne fik en svømmehal i stedet for et friluftsbad, mens Borgerlig Fællesliste med borgmester Erik Jessen i spidsen fik en placering ved Hjelmallé i stedet for en placering ved Rugkobbelskolen. Ideologisk var socialdemokratiet dog taberen i spillet, da svømmehallen blev flyttet fra skolevæsenet.

I Aabenraa havde der i forbindelse med kommunalreformen den 1. april 1970 været store problemer med at nå frem til en løsning mellem på den ene side Aabenraa købstad og de omliggende sognekommuner. Det spillede en afgørende rolle for skole- og ungdomsudvalget, da afgørelsen vedrørende svømmehallens placering skulle træffes. De nye dele af Aabenraa Kommune, Løjt og Ensted sognekommuner fik derfor også en del - om end en meget lille del - af kagen, idet man samtidig blev enig om, at der skulle opføres svømmesale ved henholdsvis Ensted Skole og Løjt Kirkeby Skole, når kommunens $\emptyset$ konomi i $\varnothing$ vrigt tillod det. Det har kommunens $\varnothing$ konomi tilsyneladende aldrig tilladt. Nok fik Løjt og
Ensted aldrig deres svømmesale, men dermed havde skole- og ungdomsudvalget givet deres lille bidrag til at bedre klimaet mellem Aabenraa købstad og de to sognekommuner. Det bidrag slog byrådet fast, da skole- og ungdomsudvalgets forslag om opførelsen af en svømme- og idrætshal fik 15 af byrådets 17 stemmer den 28. januar 1969. 21 år efter Sundhedskommissionens forbud mod tvungen skolesvømning var det tid til at handle.

Tiden var nu til at give projektet form i bogstaveligste forstand, men også at få en endelig afklaring af forholdet mellem Aabenraa Kommune og bestyrelsen for »Aabenraa-Hallen « om det fremtidige ejerskab og driften af svømme- og idrætshallen. I første omgang skulle man tage stilling til, hvem der skulle stå for opførelsen af svømme- og idrætshallen, og flere emner blev overvejet. Men med byrådets beslutning den 28. januar 1969 var afgørelsen dog reelt truffet til fordel for den lokale ingeniør G. Oesten. I første omgang skulle der udarbejdes et skitseprojekt dvs. et forslag til udformning og indretning af svømme- og idrætshallen, der skulle godkendes af skole- og ungdomsudvalget, inden man gik i gang med den mere omfattende detailprojektering, så tegninger og beskrivelser kunne anvendes som udbudsmateriale. Godt fire måneder efter, i begyndelsen af juni 1969, forelå skitseprojektet i begyndelsen af juni 1969, som blev godkendt af udvalget, men så skulle det til gengæld også gå stærkt af hensyn til kommunalreformen.

Mens Oesten sled for at gøre materialet klar, brugte skole- og ungdsomsudvalget tiden på at få klarhed over ejerskabet og driften af hallen. Udgangspunktet var Erik Jessens og formentlig også store dele af byrådets udtrykte $\emptyset$ nske om, at svømmeog idrætshallen var ejet og drevet af Aabenraa Kommune. I forsommeren 1969 
vendte byrådet imidlertid 180 grader i sagen, og efter en mild armvridning af idrættens organisationer $\varnothing$ nskede kommunen $\mathrm{nu}$, at svømme- og idrætshallen blev drevet som en selvejende institution. Baggrunden var rent $\varnothing$ konomisk. Efter at det frivillige idrætsliv siden slutningen af 1930'erne $\varnothing$ konomisk havde stået i skyggen af ungdomsundervisningen, vedtog Folketinget $\mathrm{i}$ 1968 loven om fritidsundervisning, der blev skelsættende for hele ungdoms- og fritidslivet i Danmark. Loven, der trådte i kraft 1 . august 1969, indeholdt en række nye tilskudsmuligheder for arbejdet med børn og unge under 18 år. Dette gjaldt ikke mindst på lokaleområdet, hvor kommunerne blev forpligtiget til at stille kommunale lokaler gratis til rådighed for børne- og ungdomsarbejdet, hvilket blev fortolket så liberalt, at alle foreninger, der arbejdede med børn under 25 år, kom i betragtning. Endvidere forpligtede loven kommunerne til at refundere børne- og ungdomsforeningernes udgifter til egne- eller lejede lokaler med $75 \%$ eller mindre, afhængig af andelen af medlemmer over 25 år. For kommunerne havde det tillige særlig interesse, at loven forpligtigede staten til at refundere halvdelen af kommunernes udgifter til betaling af lejede lokaler. Samtidig åbnede loven op for afdragsfri statslån med en rente på $4 \%$ til private, selvejende institutioner, hvilket dog krævede Undervisningsministeriets godkendelse af institutionens vedtægter. ${ }^{12}$ I stedet for at stille hallen gratis til rådighed for foreningerne, kunne en selvejende institution altså opkræve leje af foreningerne samtidig med, at kommunen kunne få en del af lokaletilskuddet refunderet af staten.

Den opfølgende betænkning kom i maj 1969 og var som manna fra himlen, som Aabenraa Kommune ikke var sen til at udnytte. Faktisk fremrykkede man i juni 1969 et møde med S.I.K.A., Aabenraa Amts Firmasport og svømmeklubben for netop at drøfte ejerforholdet til svømme- og idrætscenteret, så spørgsmålet kunne komme til behandling på det førstkommende byrådsmøde. ${ }^{13}$ Herefter anbefalede skole- og ungdomsudvalget byrådet, at svømme- og idrætshallen blev opført og drevet af en selvejende institution bestående af en bestyrelse på ni medlemmer, tre valgt af Aabenraa Kommune, tre af S.I.K.A. og tre af Aabenraa Amts Firmasport. Den 20. juni 1969 godkendte byrådet indstillingen med tolv stemmer. Samtidig udpegede byrådet Ingward Callesen (S), Axel Larsen (Borgerlig Fællesliste) og Curt Jertrum (Slesvigsk Parti) til det, som i første omgang var et arbejdsudvalg, som skulle stå for opførelsen af hallen. Fra S.I.K.A. stillede man kort efter med Nis Jørgensen, Hans Knudsen og Andreas Stabel til udvalget, mens Aabenraa Amts Firmasport udpegede Sv. E. Falkenberg, Johnny Holm og Henning Rohden. Med beslutningen var alle de principielle og $\varnothing$ konomiske spørgsmål ryddet af vejen og projektet for alvor sat på skinner. Tilbage stod kun det store arbejde med at få hallen bygget og med at udarbejde et sæt vedtægter for den selvejende institution, der tilfredsstillede Undervisningsministeriet og åbnede vejen for de favorable statslån.

Arbejdsudvalget gik straks i gang med at udarbejde vedtægterne for den selvejende institution, der efter bekendtgørelsen skulle udformes således, at private interesser havde hovedvægten i institutionens ledelse. ${ }^{14}$ Endvidere skulle Aabenraa Kommune have sikkerhed for, at den nye institution kunne skaffe et eget bidrag fra idrætten på $200.000 \mathrm{kr}$. som en forudsætning for at få et statslån til opførelsen, hvilket skulle foreligge senest den 11. november 1969. I begyndelsen af oktober forelå vedtægter- 


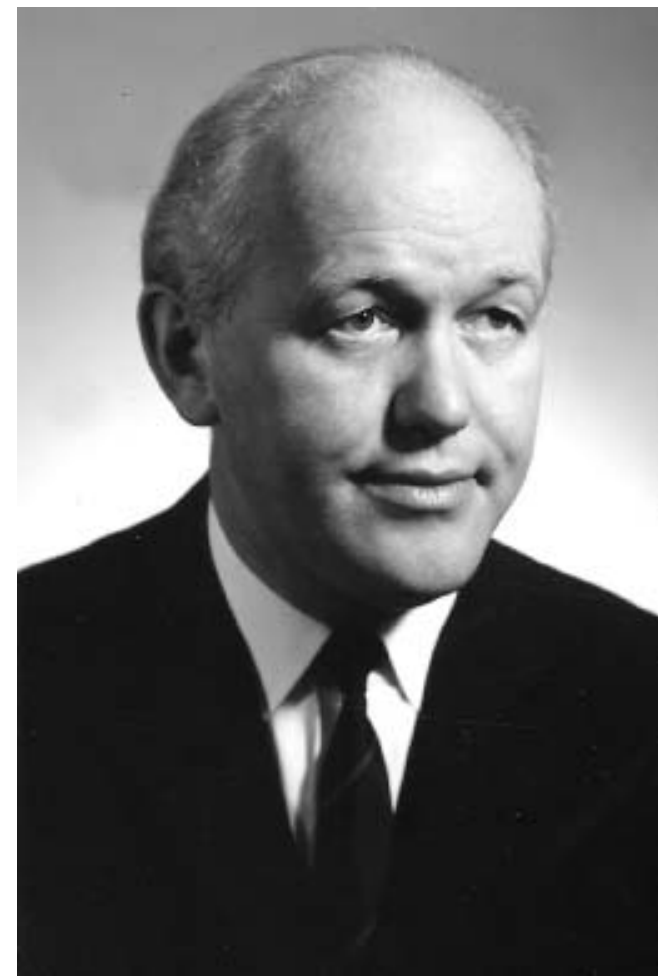

ne til godkendelse og underskrivelse af de tre parter i sagen. Den 10. oktober 1969 underskrev S.I.K.A. og Aabenraa Amts Firmasport, mens byrådet den 28. oktober godkendte vedtægterne, hvorefter borgmester Erik Jessen kunne sætte sin underskrift på dokumentet sammen med kommunaldirektør E. Haugbølle.

Vedtægterne var udarbejdet, så de spillede sammen med loven om fritidsundervisning. Efter $\S 1$ var formålet med institutionen at »tilvejebringe en svømme- og idrætshal til brug for fritidsvirksomhed for børn og unge samt til fritidsundervisning for voksne. § 2 var en opremsning af institutionens $\varnothing$ konomiske grundlag heriblandt de knap 100.000 kr., der var blevet indsamlet til svømmehallen i 1961, og de 200.000 kr., som idrætsorganisationerne havde lovet at skaffe enten kontant eller ved frivilligt arbejde. Endvidere indvilgede Aaben-
Erik Jessen (1919-2002) var Aabenraa bys markante borgmester fra 1958 til kommunalreformen i 1970. Gennem alle årene $i$ Aabenraa byråd fra han første gang blev valgt ind $i$ 1956, stillede han op for Borgerlig Fallesliste, men da han stillede op ved det første amtsrådsvalg $i 1970$ bekendte han kulør og opstillede for Venstre. Erik Jessen blev ved amtsrådsvalget partiets spidskandidat og ved konstitueringen blev hans Sønderjyllands første amtsborgmester, en post han bestred frem til 1982. Han var en varm fortaler for et friluftsbassin, som den фkonomisk bedste løsning.

raa Kommune $i$ at stille arealer til rådighed for hallen og parkeringspladsen samt udvendig belysning og beplantning, vurderet til $550.000 \mathrm{kr}$. Sammen med et forventet tilskud fra tipsmidlerne på ca. $50.000 \mathrm{kr}$. gav det et $\varnothing$ konomisk grundlag på 900.000 kr., hvilket opfyldte lovens krav til at opnå et afdragsfrit statslån til opførelse af hallen. Efter $\S 3$ fik bestyrelsen ni medlemmer efter samme fordeling som i arbejdsudvalget, så Aabenraa Kommune sad på en tredjedel af pladserne, og idrættens organisationer fik det absolutte flertal i bestyrelsen. Af hensyn til loven om fritidsundervisning indeholdt $§ 5$ en klausul, hvorefter Aabenraa Kommunes repræsentanter ikke kunne besidde hvervet som formand og næstformand. Efter samme paragraf kunne vedtægterne kun ændres eller institutionen ophøre, hvis to tredjedel af bestyrelsen stemte for, og beslutningen efterfølgende blev 
godkendt af henholdsvis Aabenraa Byråd og Undervisningsministeriet. Efter $\S 6$ skulle salg og pantsætning af fast ejendom godkendes af Aabenraa Byråd og Undervisningsministeriet. $\S 8$ indeholdt en bestemmelse, hvorefter institutionens formue ved en eventuel opløsning skulle anvendes til fremme af idrætsformål i Aabenraa Kommune efter bestyrelsens afgørelse samt kommunens og Undervisningsministeriets godkendelse. Endelig bestemte $\S 9$ at »Nærværende vedtægt vil være at forelægge S.I.K.A.'s bestyrelse, bestyrelsen for Aabenraa Amts Firma Sport, Aabenraa Byråd og Undervisningsministeriet til godkendelse«, hvilket meget direkte gav fædrene og mødrene en afgørende indflydelse på den selvejende institution.

Det skulle imidlertid vise sig, at Undervisningsministeriet efterfølgende forlangte en langt klarere adskillelse mellem den selvejende institution og Aabenraa Kommune, end de tre parter havde tænkt sig. Selve bestyrelsens sammensætning rørte ministeriet ikke ved, men de håndtag, som byrådet havde i bestyrelsen, blev forlangt fjernet. Aabenraa Byråd måtte derfor acceptere, at bestemmelsen om, at Aabenraa Kommune og Undervisningsministeriet skulle godkende vedtægtsændringer og nedlæggelse af institutionen, blev fjernet. Det samme gjaldt kravet om godkendelse af salg og pantsætning af fast ejendom samt eventuel anvendelse af formue efter nedlæggelse af institutionen, og som noget helt afgørende kunne Undervisningsministeriet heller ikke godkende, at vedtægterne efter $§ 9$ skulle godkendes af Aabenraa Kommune og Undervisningsministeriet. Ministeriet $\emptyset n-$ skede med kravene at understrege de private interessers helt afgørende indflydelse på opførelse og drift af Svømme- og Idrætshal. Den 31. oktober 1972 måtte Aabenraa Byråd derfor acceptere Undervis- ningsministeriets krav herunder, at $\S 9$ fremover havde følgende ordlyd: »Nærværende vedtægt være at forelægge S.I.K.A.'s bestyrelse og bestyrelsen for Aabenraa Amts Firmasport til godkendelse«, hvorefter borgmester Camma LarsenLedet (S) og E. Haugbølle med deres underskrifter formelt juridisk afstod fra direkte indflydelse på driften.

I oktober 1969 var det afgørende imidlertid, at byggeriet havde fået en bygherre $»$ Den selvejende institution Aabenraa Svømme- og Idrætshal «, som havde det fulde juridiske og $\varnothing$ konomiske ansvar for opførelse og drift. Ikke desto mindre var det Aabenraa Kommune, som på samme byrådsmøde, hvor vedtægterne blev godkendt, også traf den endelige beslutning om at godkende G. Oestens detailprojekt med et økonomisk overslag på 3.7 mill. kr. Herefter overlod Aabenraa Kommune det videre arbejde til den selvejende institution »Aabenraa Svømme- og Idrætshal « med at gennemføre byggeprojektet, så byggeriet kunne påbegyndes den 1. januar 1970 og afsluttes senest den 1. august 1971, idet den endelige byggepris efter en licitation med finansieringsplan skulle foreligge til byrådets godkendelse den 12. december 1970. Selv om bestyrelsen formelt juridisk var uafhængig, var der fra starten heller ingen tvivl om, hvem der havde den afgørende indflydelse på projektet. Den 10. november 1969 var den nyvalgte bestyrelse til møde på kommunaldirektør E. Haugbølles kontor for at foretage den første konstituering. På mødet deltog også ingeniør G. Oesten for at give bestyrelsen en kort redegørelse for projektet. Herefter var svømmehallens evige motor siden midten af 1950 'erne, Nis Jørgensen, formand for den nye selvejende institution, sekunderet af Sv. E. Falkenberg fra Aabenraa Amts Firmasport som næstformand og med Henning Rohden og Jens 
Chr. Schmidt som henholdsvis sekretær og kasserer.

Projektet var nu i hænderne på bestyrelsen for »Aabenraa Svømme- og Idrætshal «. Den 20. februar 1970 blev prisen for svømmehallen afsløret ved en offentlig licitation. 3,2 mill. kr. blev prisen, og arbejdet med hallen blev med få undtagelser overdraget til lokale håndværksmestre og firmaer i Aabenraa. Dermed kunne byrådet fire dage senere stille de nødvendige 3.7 mill. kr. til rådighed som et rente- $\mathrm{og}$ afdragsfrit lån betingelse af, at de indsamlede midler primært blev anvendt til byggeriet, og at kommunens teknikere fik lejlighed til at følge byggeriet ved at deltaget $\mathrm{i}$ byggem $\varnothing$ derne. ${ }^{15}$ Dermed var finansieringsspørgsmålet også blev aktuelt, idet bestyrelsen havde forpligtiget sig til at skaffe $200.000 \mathrm{kr}$. foruden de knap 100.000 kr., som var blevet indsamlet i 1961. Det var mange penge i 1970. Der blev arbejdet på højtryk for at indsamle de nødvendige $200.000 \mathrm{kr}$. og i efteråret 1971 havde man indsamlet $150.000 \mathrm{kr}$., som blev til $170.000 \mathrm{kr}$., men herefter nåede man ikke videre. Det lykkedes ikke i første omgang ved egen kraft at nå op på de 200.000 kr., men Aabenraa Kommune indvilgede i, at de $200.000 \mathrm{kr}$. i stedet blev anvendt til opførelsen af anden etape, idrætshallen. Kort tid efter modtog bestyrelsen en check på 25.000 kr. fra Sydbank A/S i anledning af 100-året for stiftelsen af Den Nordslesvigske Folkebank, der var en af de tre banker, som kort forinden var fusioneret til Sydbank. Gaven blev i den anledning overrakt af Erik Jessen, som efter kommunalreformen i 1970 var blevet amtsborgmester. Han var tidligere formand for Den Nordslesvigske Folkebank og var i denne egenskab med til at give bestyrelsen for Aabenraa Svømme- og Idrætshal en hjælpende hånd med at skaffe de nødvendige $200.000 \mathrm{kr}$.
Den 3. oktober 1971 oprandt så dagen, som mange af kommunens indbyggere havde ventet på siden slutningen af 1940'erne. Ved indvielsen betegnede borgmester Camma Larsen-Ledet det som en byhistorisk dag. Tiden efter benyttede mange af byens borgere sig af den nye mulighed for også at komme i vandet. Alene i den første uge havde svømmehallen besøg af 7.000 gæster og i løbet af de første 18 måneder besøgte 135.000 Aabenraa Svømmehal. Begejstringen ville ingen ende tage, og i anledning af åbningen beskrev Der Nordschleswiger nok meget præcist forløsningen efter mere end tyve års venten med ordene $»$ Die Badesaison nimnt kein Ende mehr «. Hverdagen i Aabenraa Svømme- og Idrætscenter kunne begynde.

\section{På vej mod en Svфmme- og Idroetshal}

Bestyrelsen og Aabenraa Kommune havde meget behændigt fået flyttet kravet om at stille med $200.000 \mathrm{kr}$. fra opførelsen af svømmehallen til opførelsen af idrætshallen. Selv om der næppe var nogen i byrådet, som var klar over det i 1970, så var det også i overensstemmelse med byrådets beslutning fra 1961, at Aabenraa Kommune ville opføre en svømmehal, hvis S.I.K.A. kunne stille med 100.000 kr. Det krav fra Aabenraa Kommune havde S.I.K.A. næsten været i stand at løfte siden begyndelsen af 1960'erne. Ud fra dette perspektiv kunne kravet om yderligere 200.000 indsamlede $\mathrm{kr}$. til byggeriet ikke være møntet på svømmehallen, uden at byrådet dermed brød sit oprindelige løfte til befolkningen i Aabenraa. Selv om bestyrelsen meget generøst havde modtaget 25.000 kr. fra Sydbank, så havde bestyrelsen stadig et stykke vej for at skaffe de resterende 
$5.000 \mathrm{kr}$. på trods af de positive meldinger i pressen ved overrækkelsen. På et møde i slutningen af juni 1972 kunne bestyrelsen dog endelig konstatere, at man havde indsamlet $198.000 \mathrm{kr}$. og havde lovning på yderlig $2.000 \mathrm{kr}$., som gjorde bestyrelsen i stand til at indfri byrådets krav. Nis Jørgensen kunne derfor anmode Aabenraa Kommune om en igangsætningstilladelse af andet byggeafsnit, idrætshallen. ${ }^{16}$ Dermed satte han også skub i et projekt, der skulle vise sig at blive helt anderledes brolagt med problemer end opførelsen af svømmehallen, selvom projektet lå klar til at tage op af skrivebordsskuffen, så snart startskuddet lød.

Starten af 1970'erne var endnu præget af en $\varnothing$ konomisk højkonjunktur, hvor bl.a. overførslen af opgaver fra staten til kommunerne og en udvidelse af det kommunale serviceniveau i kølvandet på kommunalreformen i 1970 betød en kraftig vækst i de offentlige udgifter. Denne problematik var man allerede klar over i 1970, og for at bremse den $\varnothing$ konomiske aktivitet i kommunerne sendte indenrigsminister H.C. Toft den 1. april 1970, på dagen for inddelingsreformen et cirkulære til de nyoprettede tilsynsråd, der pålagde rådene at reducere kommunernes samlede låntagning og $\varnothing$ ge selvfinansieringen. Dette ramte Aabenraa Kommune, der ikke længere var i stand til at låne de nødvendige 3-4 mill. kr. til opførelsen af idrætshallen. I forbindelse med opførelsen af svømmehallen havde man foretaget piloteringen til idrætshallen, men efterhånden som de sorte skyer trak hen over byggeriet, karakteriserede vittige hoveder i dagspressen snarere området som en kirkegård over byggeriet med hvide gravsten. ${ }^{17}$ Nu kunne bestyrelsen for den nye selvejende institution imidlertid gøre brug af de i juridisk forstand vandtætte skodder mellem Aabenraa Kommune og den selvejende in- stitution Aabenraa Svømme- og Idrætshal. Svømmehallen var ikke belånt. Hvis Aabenraa Kommune ellers gav tilladelse til det, havde bestyrelsen for Svømme- og Idrætshallen mulighed for at optage et lån $\mathrm{i}$ svømmehallen til finansieringen af idrætshallen. Dermed sneg bestyrelsen og byrådet sig uden om det kommunale lånestop. Denne kattelem gjorde Nis Jørgensen allerede kommunen opmærksom på, da han i november 1971 orienterede byrådet om status for indsamlingen. Efter forslaget skulle bestyrelsen selv optage et realkreditlån med pant i det lejede areal med bygninger (svømmehallen m.m.), hvilket kunne gøre det muligt at optage et lån til dækning af byggeomkostningerne ved opførelsen af idrætshallen. Til gengæld skulle Aabenraa Kommune to gange om året betale et tilskud til dækning af terminsydelsen for lånet. Det finansielle snilde hos Nis Jørgensen, der var bankmand, fornægtede sig ikke, men byrådet valgte den 23. november 1971 alligevel at udskyde sagen under henvisning til, at bestyrelsen endnu ikke havde indsamlet de $200.000 \mathrm{kr}$.

Den 1. juni 1972 orienterede Nis Jørgensen kommunen om, at målet var nået, underforstået at man burde sætte byggeriet i gang. Politisk var der også skred i sagen. Den 13. juni fik borgmester Camma Larsen-Ledet (S) magistratens bemyndigelse til at indlede forhandlinger med Nis Jørgensen om opførelsen af hallen, og i løbet af efteråret 1972 arbejdede bestyrelsen videre med projektet og indhentede de nødvendige lånetilbud, som gjorde det muligt at udarbejde et budgetforslag for idrætshallen med et forventet årligt driftsunderskud på ca. $580.000 \mathrm{kr}$. til afvikling af byggelånet. I foråret 1973 var det så Aabenraa Kommunes tur til at tage stilling til forslaget, som blev godkendt den 27. februar i byrådet. ${ }^{18}$ 
Arbejdet med finansieringen var derfor langt fremme, og optimismen tilsvarende stor, da regeringen den 12. april $1973 \mathrm{kom}$ med et bygge- og anlægsstop, der skulle sænke blusset i den overophedede byggeog anlægssektor i et år, som blev Danmarkshistoriens største byggeår. Bekendtgørelsen ramte ikke blot offentligt byggeri, men også byggeri, hvor en kommune stillede med garanti for lån, tilskud eller delvis dækning af anlægs- og driftsudgifterne. Stoppet skulle foreløbig vare frem til den 1. november 1973 , men efter sommerferien udsendte boligminister Helge Nielsen den 23. august en ny bekendtgørelse, der forlængede byggestoppet endnu et år frem til den 1. oktober $1974 .{ }^{19}$ I stedet for at sætte spaden i jorden måtte Nis Jørgensen i gang med at udfærdige en ansøgning om dispensation fra bygge- og anlægsstoppet, selv om han ikke var meget optimistisk, da det netop var denne form for aktiviteter, som regeringen søgte at ramme med indgrebet. I foråret 1974 begyndte dampen at gå af bygge- og anlægssektoren med de første svage stigninger i arbejdsløsheden som det første tegn på den $\varnothing$ konomiske krise, der fulgte i midten af 1970 'erne. Med

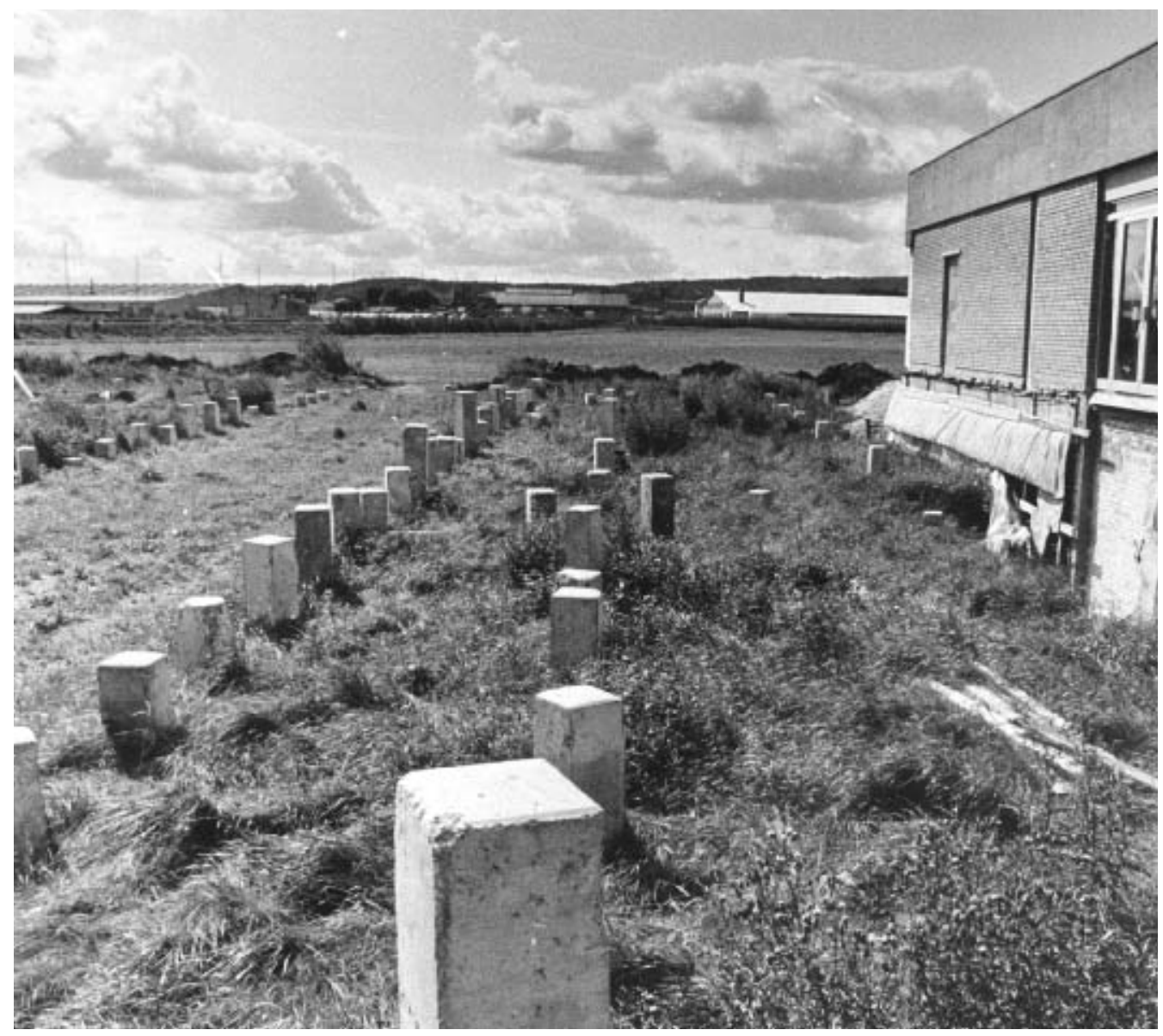

Folkeviddet døbte meget hurtigt fundamentstenene "gravsten « over idratshallen, efterhånden som opførelsen af idratshallen trak ud. Foto: Aabenraa Svømme- og Idratscenter. 
disse udsigter valgte venstreregeringen med Poul Hartling i spidsen undlade at forlænge bygge- og anlægsstoppet. Dermed var vejen banet for opførelsen af idrætshallen. Lånestoppet var der stadig, så det var fortsat bestyrelsen for Aabenraa Svømmeog Idrætscenter, der formelt stod som låntager.

Desværre havde udskydelsen af projektet også overophedet anlægsomkostninger. Den 1. januar 1971 var prisindekset for montagebyggeri på 127, den 1. januar 1972 var det vokset til 144, den 1. januar 1973 var pristallet nået op på 160, og på samme tidspunkt i 1975 lå det på 205. ${ }^{20}$ Mens G. Oestens overslag i maj 1972 lød på 3.1 mill. $\mathrm{kr}$., lød de samlede byggeomkostninger i september 1974 på 5.9 mill. kr. Den 24. september 1974 måtte byrådet derfor på ny tage stilling til finansieringen og dermed det årlige driftstilskud, som nu var vokset til 1.260.000 kr. Dette ydede byrådet gerne, idet Bent Wissing og Kjella Hansen fra Fremskridtspartiet dog undlod at stemme. ${ }^{21}$ Men der havde nu indsneget sig en »lille« detalje i finansieringen, der skulle komme til at spille en helt central rolle for Svømmeog Idrætshallens drift og økonomi de følgende ti år. Byrådsbeslutningen indeholdt nemlig en passus om, at institutionen selv skulle afholde de første 75.000 kr. af de årlige terminsydelser. Desværre ved vi ikke hvem, der er ophavsmand/kvinde til denne bestemmelse, som hvert år tvang bestyrelsen til at præstere et tilsvarende overskud på driften til medfinansiering af renteudgifterne. ${ }^{22}$ Man gætter dog næppe helt ved siden af, hvis man antager, at idéen havde sit ophav på rådhuset. Det er i alt fald vanskeligt at forestille sig, at Nis Jørgensen og bestyrelsen for svømme- og idrætshallen, som med deres forslag i forvejen havde vist stor imødekommenhed, også skulle havde stået fadder til idéen. Hermed stoppede proble- merne med finansieringen ikke, for da man endelig åbnede tilbudskuverterne den 17. december 1974 lå den billigste løsning på 7.5 mill. kr. og dermed 1.6 mill. kr. mere end G. Oestens overslag få måneder tidligere. ${ }^{23}$ På ny måtte bestyrelsen gå den tunge gang til byrådet for at sikre finansieringen af de sidste 1.6 mill. kr. Heldigvis blev bestyrelsen reddet af kursstigninger, så der »kun« manglede 400.000 kr., som bestyrelsen påtog sig at finansiere, men byrådet måtte $\mathrm{i}$ januar 1975 dog godkende et forhøjet driftstilskud og samtidig hæve lånegarantien. ${ }^{24}$

Fra oprindelig 3.1 mill. kr. i maj 1972 kom hallen i december 1974 til at koste 7.5 mill. kr., en stigning på $141 \%$ på blot 2 år med de meget betydelige konsekvenser, som det fik for driftsøkonomien. Nok tvang boligministerens bygge- og anlægsstop bestyrelsen til at udsætte byggeriet, men havde byrådet i 1971 afstået fra kravet om, at bestyrelsen skulle skaffet de sidste $25.000 \mathrm{kr}$ inden byggeriet kunne sættes i gang, havde idrætshallen været under opførelse, da bygge- og anlægsstoppet kom. Skarpt trukket op kan man hævde, at byrådets krav til bestyrelsen om at skaffe de sidste $25.000 \mathrm{kr}$. inden igangsættelsen af byggeriet kom til at koste Svømme- og Idrætshallen 4.4 mill. kr.!

Det var nu ikke den slags overvejelser, som prægede bestyrelsens arbejde i 1975 , men derimod travlhed med byggeriet, efter at det første spadestik blev taget den 13. januar. Den store festdag oprandt den 18. september 1976 med taler og en sportskavalkade med bl.a. firmasport, basketball, bordtennis, atletik, fodbold og handicapidræts på programmet. I sin tale understregede borgmester Camma Larsen-Ledet (S), at der skulle være plads til både talenter og dem, der blot vil lege. Herefter trak hun trådene op helt tilbage til etableringen af den selvejende institution Aabenraa-Hallen 
i 1967. Nis Jørgensen havde været igennem hele forløbet fra midten af 1950'erne, og han gav et noget andet historisk rids fra de første initiativer i 1959. Med en tak til de mange involverede fra håndværkerne til Aabenraa Kommune kunne Nis Jørgensen derefter give bolden op til resten af arrangementet, som blev sluttet med et »Kæmpe Hal-Bal« med optræden af bl.a. de kendte dansk-top solister Janni og Birgit Lystager. Først kl. 2 om natten stoppede musikken og lyset blev slukket. Nu kunne idrætsudøverne tage over.

\section{Halbyggeri mellem fag, politik og фkonomi}

Sundhedskommissionens forbud i 1948 mod skolernes svømmeundervisning blev indledningen til en ualmindelig langvarig politisk proces for at skabe muligheder for svømmeundervisning i Aabenraa. Når det overhovedet lykkedes at holde processen $\mathrm{i}$ gang, skyldtes det frem for andre Aabenraa Svømmeklub og S.I.K.A., der op gennem 1950'erne og 1960'erne til stadighed skubbede på for en løsning af problemet. Mest markant skete det ved etableringen af den store indsamlingskampagne i 1961 og oprettelsen af den selvejende institution $\gg \mathrm{Aa}-$ benraa-Hallen« i 1968 sammen med Aabenraa Amts Firmasport. Etableringen af Aabenraa-Hallen tvang yderst effektivt politikerne til at gå ind $\mathrm{i}$ en politisk dialog med idrætten, hvis byrådet ikke skulle miste den afgørende indflydelse på udformningen af idrætshallen og kommunens fremtidige $\varnothing$ konomiske engagement.

Omvendt var den politiske interesse frem til begyndelsen af 1960'erne mere kølig. Byrådet søgte i første omgang at løse problemerne med skolernes svømmeundervis- ning ved at opføre en søbadeanstalt, som stod færdig i 1963. På dette tidspunkt kunne badeanstalten imidlertid ikke længere tilfredsstille velfærdssamfundets krav til svømmeundervisning og svømmefaciliteter. Samtidig med opførelsen af søbadeanstalten var politikerne derfor tvunget til at gå ind i en dialog med idrætslivet i Aabenraa for at finde en ny og billig løsning, som i begyndelsen af 1960'erne var et friluftsbad. Selv om det næsten lykkedes at indsamle $100.000 \mathrm{kr}$., som var byrådets ideologiske krav for at opføre et friluftsbad, så medførte situationelle årsager og en meget langsom politisk proces i Aabenraa Kommune, at det ambitiøse projekt blev realiseret i første halvdel af 1960'erne. Resultatet af politikernes krav til idrætsforeningerne og befolkningen blev, at inflationen fuldstændig udhulede de indsamlede midler, så de i begyndelsen af 1970'erne kun udgjorde en brøkdel af byggeomkostningerne. Kravet udviklede sig i perioden 1972-1974 til det tragikomiske, da kravet om indsamling af de sidste $25.000 \mathrm{kr}$. betød, at de samlede byggeomkostninger ved opførelse af idrætshallen steg med 4.4 mill. kr. Hvad der ikke omtales i denne sammenhæng, er konsekvenserne af disse krav, som i de følgende tyve år belastede driften i et omfang, som gjorde det umuligt for bestyrelsen at sætte midler af til større vedligeholdelsesopgaver. Kombineret med fordelingen af lokalelejen mellem Aabenraa Kommune og idrætsforeningerne, hvilket i praksis har medført en meget høj lokaleleje, betød dette indirekte, at der var stærkt begrænsede midler for idrætsforeningerne til større satsninger inden for f.eks. konkurrenceidræt. Mest nærværende er problemet for svømmeklubben, hvor man endnu i dag kun har begrænsede muligheder for at tilbyde motionssvømning. ${ }^{25}$

Centralt i idrættens argument for et fri- 
luftsbassin og siden en svømmehal var hensynet til skolernes svømmeundervisning. Et svømmebad gjorde det muligt at drive og tilrettelægge en bedre svømmeundervisning for kommunens skolebørn, lød det fra S.I.K.A. og Aabenraa Svømmeklub langt op i 1960'erne. Knap så højt lød kravet om faciliteter til motionister og konkurrencesvømning. Argumentationen om hensynet til skolernes svømmeundervisning overtog politikerne, da de fra midten af 1960 'erne for alvor begyndte at komme på banen i spørgsmålet. Men da den politiske proces fra starten ikke fulgte med de nye tekniske muligheder og velfærdsstatens voksende krav til svømmefaciliteter, og da politikerne ikke var klar over dette, gjorde Ostenfeld \& W Jønson dem gerne opmærksom på de nye muligheder og krav. Endnu i 1961 var der i forbindelse med indsamlingen af penge til friluftsbadet politisk enighed om mål og midler, men fra 1964/65 skete der en politisk spaltning først langsomt, men siden udviklede diskussionen sig til et voldsomt politisk slagsmål, som til tider udviklede sig til meget personlige angreb. På den ene side stod en borgerlig fløj ledet af Borgerlig Fællesliste med borgmester Erik Jessen i spidsen, som ønskede et friluftsbassin, den billige løsning, men som også tilgodeså idrættens behov. På den anden side stod Socialdemokratiet ledet af tidligere borgmester Georg Buchreitz, som ønskede en svømmehal placeret ved en af skolerne som den nye og bedre, men også dyrere løsning. Der var dog også internt i de to fløje af byrådssalen uenighed om den rette løsning, hvilket fik konsekvenser for den politiske proces i løbet af 1960'erne.

For at generobre initiativet, da idrætsorganisationerne etablerede Aabenraa-Hallen i 1968 for at bygge og drive en idrætshal, forlangte Erik Jessen, at Aabenraa
Kommune skulle opføre og drive hallen. Idrætsforeningerne skulle efter hans opfattelse ikke bruge deres tid og resurser på at drive en hal, men på arbejdet med børn og unge. Idrætslivet i Aabenraa $\emptyset$ nskede lige så klart, at de frivillige organisationer byggede og drev den nye svømme- og idrætshal, men accepterede nødtvungent efter Erik Jessens krav, at Aabenraa Kommune stod for opførelsen og driften af hallen. Da fritidsloven fra 1968 og den opfølgende bekendtgørelse i maj 1969 betød, at kommunen fremover skulle stille sine lokaler gratis til rådighed for idrætslivet, skiftede Erik Jessen i slutningen af maj 1969 holdning i spørgsmålet. Idrætsorganisationerne havde bestemt intet imod denne kovending i sagen, og resultatet blev etablering af den selvejende institution »Aabenraa Svømmeog Idrætshal «, som skulle stå for opførelsen og drift. Dermed kunne kommunen nøjes med at yde et tilskud til idrætsforeningernes halleje, som blev delvis refunderet af staten. Det var dog ikke udtryk for et $\emptyset$ nske fra kommunens side om en fuldstændig frigivelse af den nye selvejende institution. Tværtimod indeholdt de oprindelige vedtægter en kraftig binding af bestyrelsen for den selvejende institution, men efter at vedtægterne havde rundet Undervisningsministeriet, måtte Aabenraa Kommune acceptere, at en række kommunale bindinger skulle slettes af vedtægterne. Dermed var bestyrelsen for Aabenraa Svømme- og Idrætshal juridisk suveræn. Noget andet er så, at byrådet allerede fra midten af 1970'erne begyndte at begrænse bestyrelsens handlefrihed politisk som $\emptyset$ konomisk, så den fik meget begrænsede muligheder for bl.a. at lægge midler til side til større vedligeholdelsesopgaver og langsigtede investeringer.

Den politiske proces kulminerede i 1967 og 1968 med et politisk spin, hvor Social- 
demokratiet nok fik en svømmehal, men hvor det lykkedes for borgmester Erik Jessen at flytte hallen ud af skoleregi og over i en selvejende institution, der stod for driften af såvel svømmehallen som idrætshallen. Socialdemokratiet fik ganske vist en svømmehal, hvad der endnu ærgrede Erik Jessen, da han få år før sin død udgav sine erindringer, men partiet tabte ideologisk. Svømmehallen fik et langt bredere sigte end den skoleundervisning, der oprindeligt var hensigten for Socialdemokratiet. Når socialdemokraten Ingward Callesen ved den afsluttende byrådsdebat om sagen henviste til byens gode badestrande, så var det

\section{Noter}

1 Artiklen er nogle af konklusionerne i manuskriptet til en bog med arbejdstitlen »Aabenraa Svømmeog Idrætscenter 1948-1986«, som er under udgivelse.

2 Bekendtgørelse nr. 153 af 24. marts 1939 om Svømmeprøver for Skoleelever. Cirkulære af 10. maj 1939 til samtlige Skoledirektioner og til Byraadene uden for de sønderjydske Landsdele angaaende Svømmeundervisning i Skolerne.

3 Opførelsen blev på snedig vis bl.a. finansieret af Statens Vejfond fuldt legalt.

4 Svømmehaller fik deres gennembrud i 1930'erne, hvor der blev bygget store imposante svømmehaller i de største byer ofte kombineret med badeanstalter. I det perspektiv er svømmehallerne halmæssige symboler på den danske velfærdsstat, som i disse år skød op i de fleste større provinsbyer. Se i øvrigt Betænkning nr. 1094 om breddeidrætten i Danmark. Kbh. 1987, bd. II s. 305, og Hans Lyngsgård: »Idrættens rum. Nybrud i idrættens arkitektur« København 1990, s. $120 \mathrm{ff}$.

5 S.I.K.A.'s medlemsblad, juli 1957.

6 Undervisningsministeriets cirkulære af 4. august 1959 vedrørende anlæg og indretning af svømmebassiner.

7 Aabenraa Kommune. Borgmesterkontoret. J.nr. 29-2-6. Opførelsen af svømmebad.

8 Aabenraa Kommune. Borgmesterkontoret. J.nr. 29-2-6. Opførelse af svømmehal.

9 Aabenraa Kommune. 29-2-6 Opførelsen af et Svømmebad. dybest set et udtryk for, at svømning og badning efter hans opfattelse foregik ved stranden. Friluftsbade og svømmehaller skulle kun være rammer om svømmeundervisning, så befolkningen ikke druknede ved strande og søer. Velfærdsstaten i slutningen af 1960'erne havde ikke blot forældet Erik Jessens ønske om et friluftsbassin, men også Socialdemokratiets og andres opfattelse af svømmehallen som ramme for skolernes svømmeundervisning. Svømmehallen havde op gennem 1960'erne udviklet sig til at være velfærdsstatens alternativ til de offentlige strande.

10 S.I.K.A.'s arkiv. 1967-1968. Forhandlingsprotokol fra Haludvalget.

11 Gunnar Lind Haase Svendsen: »Den gode vilje « i: Sønderjyske Årbøger 2002, s. 227-242.

12 Lov nr. 233 af 6. juni 1968 om fritidsundervisning m.v. Bekendtgørelse nr. 302 af 14. maj 1969 om etablering af lokaler m.v. til virksomhed inden for lov om fritidsundervisning m.v. Betænkning nr. 709 om Idrætten og friluftslivet afgivet af det af ministeren for kulturelle anliggender den 14 . marts 1970 nedsatte udvalg. København 1974, s. 102-106.

13 Aabenraa Kommune. Borgmesterkontoret. Journalsager j.nr. 29-2-6. Brev af 11. juni 1969.

14 Bekendtgørelse nr. 302 af 14. maj 1969 om etablering af lokaler m.v. til virksomhed inden for lov om fritidsundervisning m.v. $\S 6$.

15 Aabenraa Kommune. Teknisk Forvaltning. Byggesager vedrørende Hjelmallé 3.

16 Aabenraa Svømme- og Idrætscenter. Bestyrelsesreferat 31. juni 1972.

17 Aabenraa Svømme- og Idrætscenter. Presseudklip. Udklip »Idrætshallen må vente« og »Klar til idrætshal - skaf blot pengene .

18 Aabenraa kommune. Borgmesterkontoret. 25.4 1972-27.3 1973. Byrådets forhandlingsprotokol.

19 Bekendtgørelse nr. 199 af 12. april 1973 om udsættelse af visse bygge- og anlægsarbejder og bekendtgørelse nr. 482 af 23. august 1973 om udsættelse af visse bygge- og anlægsarbejder.

20 Statistisk Årbog 1973, s. 235 og 1975 s. 277. 
21 Aabenraa Kommune. Borgmesterkontoret. 1.4 1974 - 31.31975 . Byrådets forhandlingsprotokol.

22 Sagsakterne til byrådets beslutning den 24. september 1974 ses hverken i borgmesterkontorets eller skoleforvaltningens arkiv.

23 Aabenraa Kommune. Borgmesterkontoret. J.nr. 29-2-6. Licitation vedrørende idrætshallen ved Hjelmallé.

\section{Litteratur}

Henrik Becker-Christensen og Jørgen Witte, Fra købstad til storkommune. Aabenraa bys historie bd. 4, 1945-1970« (Aabenraa 1985).

Betænkning nr. 709 om idrætten og friluftslivet, (København 1974).

Betænkning nr. 1016 om fritidsvirksomhed for børn og unge, (København 1984).

Betænkning nr. 1094 om breddeidrætten i Danmark, (København 1987).

Betænkning nr. 1164 om vilkår for tilskud til folkeoplysning, (København 1989).

Claus Bøje, Fra sportsbassin til superbassin. Bemærkninger til en udvikling i vandkulturen, (København 1997).

C. Dyrbye, »Chr. Ostenfeld « I: Bygningsstatistiske meddelelser 1977, s. 1-4 (nekrolog).

Kim Furdal, »Kommunalreformen « I: Per: Boje: Folkestyre i by og på land. Danske kommuner gennem 150 år, (1991), s. 141-160.

Kim Furdal, »Aabenraa Svømme- og Idrætscenter 1948-1986«. upl. manuskript.

Tyge Hvass og W. Jønson, »Bellahøj-Badet« I: Byggeindustrien 1960, s. 315-320.

Erik Jessen, Bare han får sin vilje, (Aabenraa 1997).

Arne Levin, og Chr. Ostenfeld, »Ballerup idrætspark « I: Havekunst 1964, s. 61-64.

Hans Lyngsgård, Idrættens rum. Nybrud i idrættens arkitektur, (København 1990).

Erik Nygaard, Tag over hovedet. Dansk boligbyggeri fra 1945 til 1982, (København 1984).

Ostenfeld, Chr. og W. Jønson: »Nogle nye idrætsan$l_{\text {}}$ « i: Dansk Teknisk Tidsskrift nr. 2, 1946, s. 25 36.

Chr. Ostenfeld, og W. Jønson, »Kolding kommunes badeforhold « I: Tidsskrift for kommunalteknisk chefforening 1954, s. 115-125.

SIKA's medlemsblad 1957-1973.

Gunnar Lind Haase Svendsen, »Den gode vilje« I: Sønderjyske Årbøger 2002, s. 227-242.
24 Aabenraa Kommune. Borgmesterkontoret. 1.4 1974 - 31.31975 Byrådets forhandlingsprotokol.

25 Problemstillingen er nærmere beskrevet i Kim Furdal: »Aabenraa Svømme- og Idrætscenter 1948-1986«.

\section{Kilder}

Landsarkivet for Sønderjylland 1920-1970. Aabenraa Kommune.

Borgmesterkontoret. J.nr. 29-1-1; 29-2-6; 29-3-4; 29-3-5.

Aabenraa Kommune

1969-1982. Borgmesterkontoret.

Journalsager. J.nr. 29-2-6. Sager vedrørende Aabenraa Svømme- og Idrætscenter.

1982-Skoleforvaltningen.

Journalsager vedr. Aabenraa Svømme- og Idrætscenter.

1969-Teknisk Forvaltning.

Byggesagsarkiv. Hjemallé 3.

SIKA's arkiv

1968-1969. Bestyrelsesprotokol for »Aabenraa-Hallen $\ll$

1959-1963. Bestyrelsesprotokol for »Forhandlingsprotokol for udvalget for Aabenraa Svømmebad «.

Aabenraa Svømme- og Idrætscenter

1968-1984. »Aabenraa-hallen«, vedtægter, regnskaber og avisudklip.

1969-1988. Referater fra bestyrelsesmøder og forretningsudvalgsmøder.

1971-1982, 1985-1986. Bestyrelses- og FU-referater. 1986-1988. Bestyrelsen.

1977-1983. FU- og byggeudvalgsmøder.

1967, 1978-1985. Haludvalget og halfondudvalget.

1969-1976. Opførelsen af hal I.

1984-1986. Opførelsen af hal II.

1982-1991. Meddelelser til klubberne og pressen.

1979-1984. Diverse sager.

1971-1975. Udklip. Svømmehallen.

1973-1982. Udklip. Idrætshallen. 


\section{Lovgivning, bekendtgørelser og cirkulære}

Bekendtgørelse af 24. marts 1939 om Svømmeprøver for Skoleelever.

Cirkulære af 10. maj 1939 til samtlige Skoledirektioner og til Byraadene uden for de sønderjydske Landsdele angaaende Svømmeundervisning i Skolerne.

Cirkulære af 4.81959 vedrørende anlæg og indretning af svømmebassiner.

Lov nr. 233 af 6.61968 om fritidsundervisning m.v.

Bekendtgørelse nr. 300 af 14.51969 om fritidsvirksomhed for børn og unge.

Bekendtgørelse nr. 302 af 14.51969 om etablering af lokaler m.v. til virksomhed inden for lov om fritidsundervisning m.v.

Bekendtgørelse nr. 199 af 12.41973 om udsættelse af visse bygge- og anlægsarbejder.

Bekendtgørelse nr. 482 af 23.81973 om udsættelse af visse bygge- og anlægsarbejder.

\section{Aviser}

Sønderjyden 9.4 og 7.121961.

Hejmdal 30.5, 2.51963 og 4.101971.

Jydske Tidende 3.9, 10.7 og 9.81983 samt 15.7, 24.10 og 3.121984 .

Vestkysten 14.121983 og 16.71986.

Aabenraa Ugeavis 9.2 og 16.3, 1983. 